\title{
Changes in biochemical analytes in calves infected by nematode parasites in field conditions ${ }^{2 / 2}$
}

\author{
Marcela C. de Cezaro ${ }^{\mathrm{a}}$, Asta Tvarijonaviciute ${ }^{\mathrm{b}}$, Fernando Tecles $^{\mathrm{b}}$, José J. Céron ${ }^{\mathrm{b}}$, \\ David P. Eckersall ${ }^{\mathrm{c}}$, João C.P. Ferreira ${ }^{\mathrm{d}}$, Elizabeth M.S. Schmidt ${ }^{\mathrm{a}, *}$ \\ a Department of Veterinary Clinical Sciences, School of Veterinary Medicine and Animal Science, São Paulo State University (FMVZ-UNESP), Campus of \\ Botucatu, SP, Brazil \\ ${ }^{\mathrm{b}}$ Interdisciplinary Laboratory of Clinical Pathology, Interlab-UMU, Campus of Excellence Mare Nostrum, University of Murcia, Spain \\ ${ }^{\mathrm{c}}$ Institute of Biodiversity, Animal Health and Comparative Medicine, College of Medical, Veterinary and Life Sciences, University of Glasgow, UK \\ d Department of Animal Reproduction and Radiology, School of Veterinary Medicine and Animal Science, São Paulo State University (FMVZ-UNESP), \\ Campus of Botucatu, SP, Brazil
}

\section{A R T I C L E I N F O}

\section{Article history:}

Received 26 November 2015

Received in revised form 19 January 2016

Accepted 21 January 2016

\section{Keywords:}

Haptoglobin

Acetylcholinesterase

Cholesterol

Cooperia spp.

Dictyocaulus viviparus

Nematodes

\begin{abstract}
A B S T R A C T
Parasitic infections caused by nematodes are a major problem in bovines that resulting in losses in animal health and production. Thus, the aim of this study was to evaluate alterations in selected serum biochemical analytes in calves naturally infected with gastrointestinal (GI) and pulmonary nematodes without clinical signs. For this, samples of feces and blood of 86 calves were collected. Fecal egg counts (FEC) were determined using the modified McMaster technique with a sensitivity of 50 eggs per gram of feces (EPG). Positive nematode FEC was processed for coproculture using pooled samples to identify Strongylidae infective larvae (L3). First stage-larvae (L1) of Dictyocaulus viviparous were identified by a modified Baermann method. The biochemical analytes determined were: acute phase proteins such as haptoglobin and paraoxonase type 1; the enzymes acetylcholinesterase; butyrylcholinesterase; the lipid profile (triglycerides and total, HDL, and LDL-cholesterol); serum iron profile (iron and unsaturated iron-binding capacity); total protein and albumin; pancreatic profile (amylase and lipase); and minerals (phosphorus and calcium). The calves were divided into four groups according to the results of EPG and the modified Baermann method. Group 1: healthy control animals $(n=16)$; Group 2: calves with only GI parasites $(n=51)$ : This group was sub-divided into sub-groups according to the EPG threshold: $2 \mathrm{a}-\mathrm{GI}$ parasites with low EPG $(n=23)$, and $2 b-G I$ parasites with high EPG $(n=28)$. Group 3: animals with only lungworms $(n=5)$, and Group 4: calves with lung + GI parasites $(n=14)$. The more prevalent genera in all coprocultures were: Cooperia spp., Haemonchus spp., Oesophagostomum spp., and Trichostrongylus spp. The nonparametric Kruskal-Wallis test was used to compare the groups and Dunn's post-test was used for multiple comparisons as the data was not normally distributed $(P<0.05)$. The haptoglobin concentration increased in calves with GI and pulmonary parasites. A significant increase in acetylcholinesterase was observed in calves infected with lungworms. Cholesterol, triglycerides, HDL, and LDL concentrations decreased but lipase concentration increased in calves with GI parasites. Therefore, this paper provides an overview of the biochemical effects produced by nematode parasites in calves in field conditions. These findings in calves without any evident clinical signs of disease could provide an indication of GI parasites and lungworm infection, especially in an endemic area for these parasites.
\end{abstract}

(c) 2016 Elsevier B.V. All rights reserved.

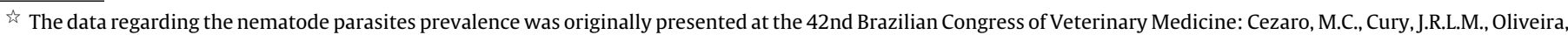

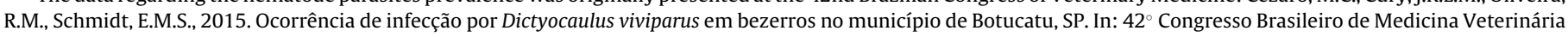
e $1^{\circ}$ Congresso Sul-Brasileiro da ANCLIVEPA, Curitiba, 0204-0208 PR, Brazil.

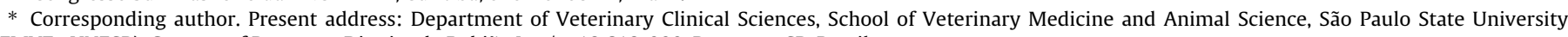
(FMVZ-UNESP), Campus of Botucatu, Distrito de Rubião Jr, s/n. 18.618-000, Botucatu, SP, Brazil.

E-mail addresses: bethschmidt@fmvz.unesp.br, schmidt.beth@gmail.com (E.M.S. Schmidt).
} 


\section{Introduction}

Parasitic infections caused by nematodes in cattle are a major health problem around the world. Disease caused by nematodes both in clinical and subclinical presentations result in major losses to animal health and production (Charlier et al., 2009). In Brazil, the distribution of these parasites is favored by the predominance of tropical and subtropical climates. Estimated economic losses caused by gastrointestinal (GI) nematodes are around 7.11 billion dollars/year in Brazil (Grisi et al., 2014).

The most frequent GI nematodes in cattle in São Paulo State in southeastern Brazil are: Haemonchus spp. and Ostertagia spp., parasites of the abomasum; Cooperia spp., Trichostrongylus spp., and Strongyloides spp., parasites of the small intestine and Oesophagostomum spp., parasite of the large intestine. Additionally, the lung nematode Dictyocaulus viviparous has been reported in ruminants in São Paulo State (Oliveira, 1988; Gonçalves et al., 2000; Borges et al., 2001; Landim et al., 2001). These species of gastrointestinal nematodes are reported to be present worldwide (Keyyu et al., 2005; Holland et al., 2000; Jiménez et al., 2010), while, D. viviparous is most frequently described in temperate climates (Ploeger., 2002; Wapenaar et al., 2007; Lat-Lat et al., 2010). For all these parasites, the definitive host is infected by ingestion of infective larvae (L3) from contaminated pasture (Anderson, 2000) with the infection, in general being caused by mixed nematode species.

A variety of pathological effects occur during infection with these parasites such as anemia, weight loss, anorexia, dehydration, diarrhea, and submandibular edema (bottle jaw) among others (Taylor et al., 2007; Hogg et al., 2010), and when the lung parasite is also present, there could be coughing and tachypnea (Anderson, 2000; Silva et al., 2005). The clinical presentations of cattle with these parasitic infections differ by multiples factors, including the age of the animal. Calves are highly susceptible, because of the immature immune system, thus, in their first grazing season they commonly display clinical signs (Höglund et al., 2001). However, in many cases, individuals with a high parasite burden may not show any clinical signs. These subclinically infected calves are potential contaminators of pasture for the other animals (Taylor et al., 2007). Additionally, there is a decrease in production and weight gain, resulting in delayed development and furthermore this condition also adversely affects the animal's welfare (Gibbs, 1992).

We hypothesized that calves infected with GI and/or pulmonary nematodes but without clinical signs have changes in selected biochemical analytes related to inflammation, lipid and iron metabolism, pancreatic function and Ca-P metabolism, which could be used as tools to raise the possibility of infection despite the absence of clinical signs. Therefore, the aim of this study was to evaluate a panel of various serum analytes in calves naturally infected with GI and pulmonary nematode but without clinical signs. For this purpose the concentrations of selected acute phase proteins: haptoglobin (Hp), and paraoxonase-1 (PON-1), the enzymes acetylcholinesterase (AChe) and butyrylcholinesterase (BChe), a lipid profile (cholesterol, triglycerides, HDL, and LDL), a serum iron profile: iron and unsaturated iron-binding capacity (UIBC), total protein and albumin, a pancreatic profile (amylase and lipase) and minerals (phosphorus and calcium) were determined.

\section{Material and methods}

\subsection{Animals}

The study population comprised 86 crossbreed (Holstein $\times$ Girolanda) calves from 2 to 24 months old. The animals belonged to two small private farms in the municipalities of Botucatu and Manduri, São Paulo State, in the southeastern region of
Brazil. The calves were monitored for 12 months (from September 2014 to August 2015). Blood and feces samples were collected every three months during the same week for both farms. This study was approved by the Faculty's Animal Experimentation Ethics Committee of the São Paulo State University-FMVZ, UNESP, Botucatu (18/2015-CEUA).

The calves were monitored clinically in both farms by weekly veterinary inspections, including a general visual inspection, evaluation of body condition score, oral mucous membranes examination, feces visual inspection, and rectal temperatures measurements. The animals were considered to be healthy if they did not show any evident clinical signs at the inspection and had rectal temperatures less than $39.5^{\circ} \mathrm{C}$. The animals were vaccinated for foot and mouth disease, and brucellosis according to current legislation in the Animal Health National Programs in Brazil (MAPA, 2009).

\subsection{Fecal testing}

Samples of feces were collected directly from the rectum of each animal and stored in a labeled plastic bag. Feces were transported at $4{ }^{\circ} \mathrm{C}$ to the Laboratory of Animal Parasitic Diseases of the Veterinary Teaching Hospital of the Faculty of Veterinary Medicine and Animal Science (FMVZ), Botucatu, São Paulo State, Brazil for analysis. Fecal egg counts were determined using the modified McMaster technique with a sensitivity of 50 eggs per gram of feces (EPG) (Gordon and Whitlock, 1939). Depending on the EPG results, the animals were divided into subgroups, according to the threshold defined by Vercruysse and Claerebout (2001) and Antonello et al. (2010). Positive nematode egg feces were processed for coproculture (Roberts and O'Sullivan, 1950). In brief, coprocultures were prepared by mixing approximately $2 \mathrm{~g}$ of feces from each EPG positive animal to make farm pools which were macerated with distilled water, sterilized wood shavings, and incubated at $27^{\circ} \mathrm{C}$ for seven days. One hundred larvae were counted under a microscope and the results were expressed as the proportion (\%) of L3 recovered. Identification of Strongylidae infective larvae (L3) and the percentage of L3 were determined according to Ueno and Gonçalves (1998), Amarante, (2011) and Van Wyk and Mayhew (2013), using pooled samples. Fecal first larval stage (L1) of $D$. viviparus was determined by a modified Baermann method described by Rugai et al. (1954).

\subsection{Blood analysis}

Blood samples were collected from the jugular vein in plain tubes with gel separators, which were allowed to clot at room temperature for $30 \mathrm{~min}$. After centrifugation $(1500 \times g$ for $5 \mathrm{~min})$ sera were stored in Eppendorf microtubes at $-20^{\circ} \mathrm{C}$.

\subsubsection{Biochemical profile}

Serum haptoglobin concentrations were measured via a hemoglobin binding assay previously validated for use in bovine (Eckersall et al., 1999). Serum PON-1 was determined using pnitrophenyl acetate as substrate in an automated clinical chemistry analyzer (Olympus AU2700, Olympus Diagnostica GmbH) using an adaptation of a previously described assay (Tvarijonaviciute et al., 2012).

The Ache and BChe concentrations were determined using previously described method (Tecles and Cerón, 2001) adapted to an automated analyser (Olympus AU400, Olympus Diagnostica $\mathrm{GmbH}$ ).

Total serum cholesterol, triglycerides, HDL and LDL; total protein, albumin; amylase, lipase, calcium, and phosphorus were measured using an automated analyzer (Olympus AU600, Olympus Diagnostica $\mathrm{GmbH}$ ), following the instructions of the manufacturer using Olympus commercial kits. 


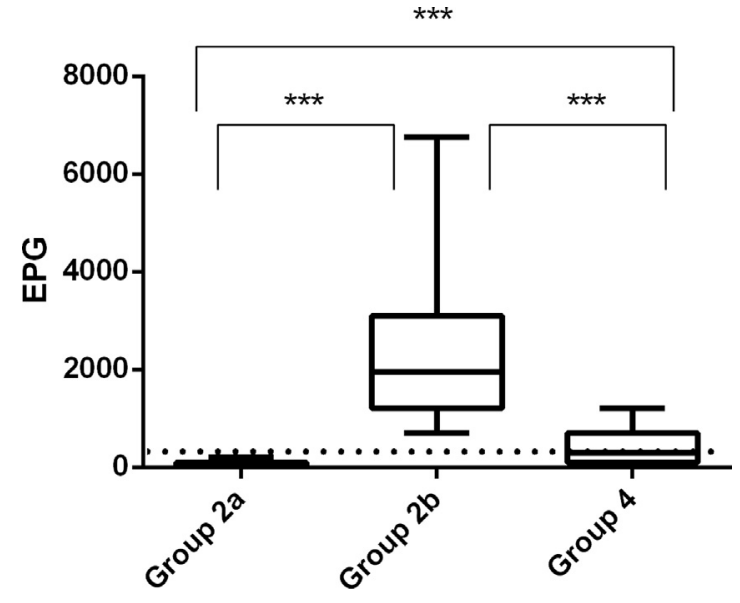

Fig. 1. Fecal egg counts (eggs per gram of feces-EPG) among calves naturally infected by GI parasites (Groups 2a and 2b), and with lung + GI parasites (Group 4). Horizontal dotted line (200 EPG threshold). ${ }^{* * *} P<0.0001$. Groups 1 and 3 are not included $(E P G=0)$.

Serum iron (Iron OSR6186, Beckman Coulter), and the unsaturated iron-binding capacity (UIBC) (UIBC OSR6124, Beckman Coulter) concentrations were determined via quantitative assays with an automated analyzer (Olympus AU2700, Olympus Diagnostica $\mathrm{GmbH}$ ).

All the intra and inter-assays showed a within run variation of less than $10 \%$.

\subsection{Statistical analysis}

Statistics were performed using the statistical software (GraphPad Prism Version 6 for Windows, GraphPad Software, San Diego, CA, USA). Data are reported as median, percentiles (25 and 75\%), and range (minimum and maximum) unless otherwise stated. All variables were first assessed for normality using the Shapiro-Wilk test. The nonparametric Kruskal-Wallis test was used to compare the groups and Dunn's post-test was used for multiple comparisons as the data was not normally distributed. Statistical significance was set at $P<0.05$ for all analyses.

\section{Results}

The calves were divided into four groups according to the results of the EPG and by modified Baermann method. Group 1 consisted of 16 healthy control animals (negative EPG, and negative modified Baermann); Group 2 consisted of 51 calves with only GI parasites (EPG positive and negative modified Baermann). This group was sub-divided into sub-groups: $2 \mathrm{a}-\mathrm{GI}$ parasites with low $\operatorname{EPG}(n=23)$ and $2 \mathrm{~b}-\mathrm{GI}$ parasites with high EPG $(n=28)$ according to the EPG threshold (Group 2a: <200; Group 2b: >200) (Vercruysse and Claerebout, 2001; Antonello et al., 2010). Group 3 consisted of five animals with only lungworms (EPG negative and positive Baermann method), and Group 4 consisted of 14 calves with lung + GI parasites (positive EPG and positive Baermann method) (Fig. 1). First larval stage of $D$. viviparus was identified in calves of groups 3 and 4, and the more prevalent genera in all coprocultures were: Cooperia spp., Haemonchus placei, Oesophagostomum spp. and Trichostrongylus spp., respectively, for all animals of groups $2 \mathrm{a}, 2 \mathrm{~b}$, and 4. Both farms showed the same prevalent genera of GI nematodes and were small dairy properties with very similar hygiene sanitary system.

Biochemistry analytes in healthy and infected calves are presented in Fig. 2. The groups with GI parasites with high EPG (Group 2b), lungworm only (Group 3) and lung + GI parasites (Group 4) had significant higher concentrations of haptoglobin than the healthy control group. In addition, the groups with lungworms had significant higher AChe concentrations compared with the healthy group and groups with only GI parasites (Group 2 ).

The group of GI parasites with high EPG (Group 2b) showed a significant decrease of the lipid profile analytes: triglycerides $(1.2 \times$ fold decrease), total cholesterol ( $1.5 \times$ fold decrease), $\mathrm{HDL}(1.4 \times$ fold decrease), and LDL $(1.1 \times$ fold decrease) compared with the control and the lung + GI parasites (Group 4) groups. In addition, in the animals with GI parasites, the group with high EPG had lower total cholesterol (1.6x fold decrease) and LDL-cholesterol concentrations $(1.3 \times$ fold decrease) than the low EPG GI parasites group (2a).

The groups of GI parasites ( $2 \mathrm{a}$ and $2 \mathrm{~b}$ ) showed significant higher concentrations of lipase than the control and the lung + GI parasites groups (Group 4).

Iron, UIBC, total protein, albumin, amylase, phosphorus, calcium, PON-1, and BChe concentrations were not significantly different among the groups (Table 1 ).

\section{Discussion}

The GI parasites genera found in our study were Cooperia spp., Haemonchus spp., Trichostrongylus spp. and Oesophagostomum spp. The lung parasite identified in our study was $D$. viviparus. These parasites were also the most prevalent observed in previous reports from different parts of Brazil: São Paulo, Rio de Janeiro, and Minas Gerais State (Oliveira, 1988; Gonçalves et al., 2000; Borges et al., 2001; Landim et al., 2001; Neto and Fonseca, 2002; Bruhn et al., 2012), as well in other countries with similar climates, characterized by two well-defined periods: a rainy season (summer) and a dry season (winter), such as in Costa Rica (Jiménez et al., 2010), and Vietnam (Holland et al., 2000).

In our study, $\mathrm{Hp}$ increased in all the groups of animals with parasites except the group with low amount of GI parasites. This would indicate that the parasites, when presented in high amounts, could produce an inflammatory status in calves, since $\mathrm{Hp}$ is a major acute phase protein in ruminants (Ceciliani et al., 2012). In the case of GI parasites, the cause of increases in Hp could be the damage caused to the GI tract, whereas in the lung parasites the increases in Hp could reflect subclinical chronic parasitic bronchitis and pneumonia caused by D. viviparous infection (Radostits et al., 2007). Increased $\mathrm{Hp}$ concentrations in calves were described in experimental D. viviparous and Eimeira zuernii infections (Gånheim et al., 2004; Lassen et al., 2015).

In $D$. viviparous experimental infection, the $\mathrm{Hp}$ concentration showed a peak 14 days after inoculation with L3 larvae, and although the animals had clinical signs of the infection (Gånheim et al., 2004), the Hp concentration was similar to our findings. These results were also similar to experimental infection with oocysts of Eimeria zuernii in calves, as Hp concentration peaked at 24 days after inoculation (Lassen et al., 2015), reaching similar Hp concentrations that were found in the group of GI parasites, demonstrating an inflammatory response caused by the effect of nematode and protozoan parasites in the small intestine mucosae.

The increased AChe concentrations found in calves with pulmonary parasites in the present study could reflect the secretion of AChe by the parasites, as D. viviparous and GI parasites such as Oesophagostomum spp., Trichostrongylus spp. which are known to secrete this enzyme (Lee, 1996; McKeand et al., 1994). The release of AChe by the parasites is influenced by various factors such as: species, life cycle, and gender of the parasite (Lee, 1996). A hypothesis explaining why animals with pulmonary parasites present higher serum AChe activity compared with GI parasites, would be that $D$. viviparous has close contact with the pulmonary 


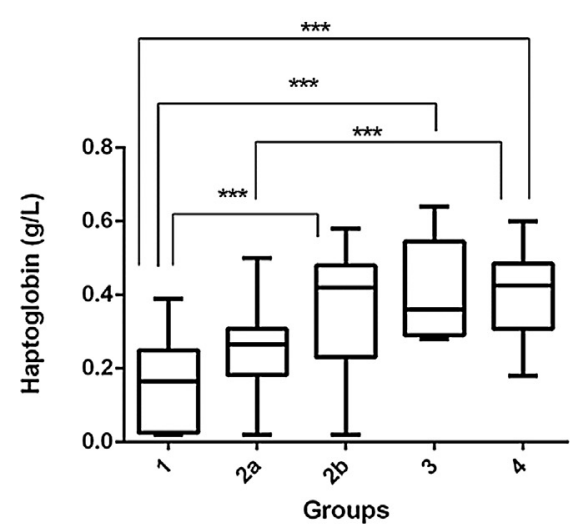

A

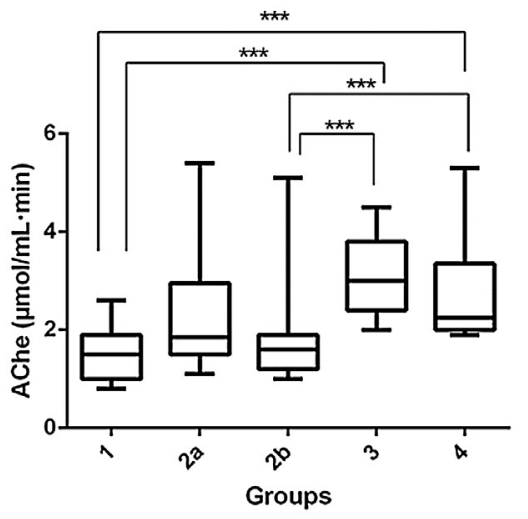

B

C
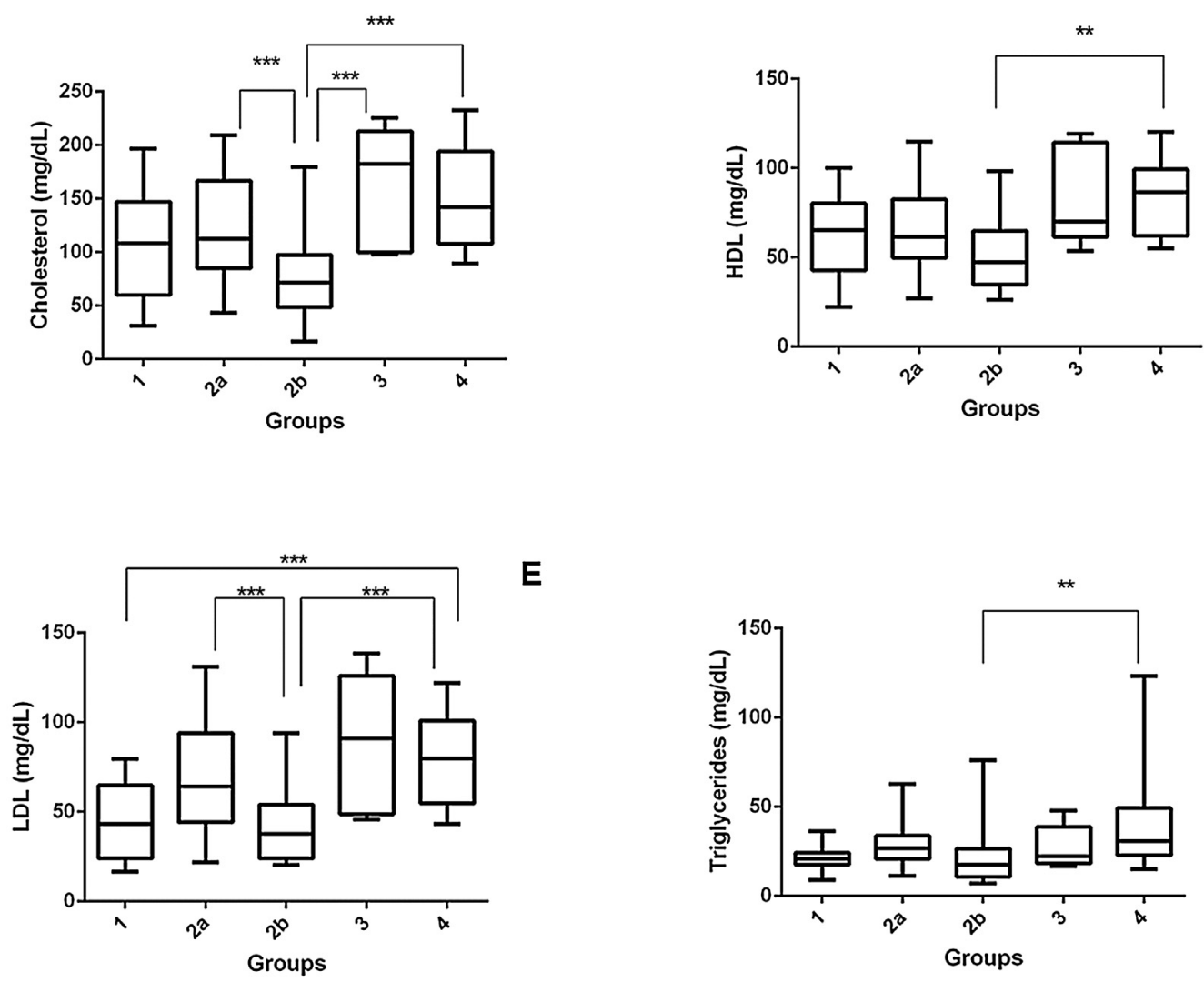

E
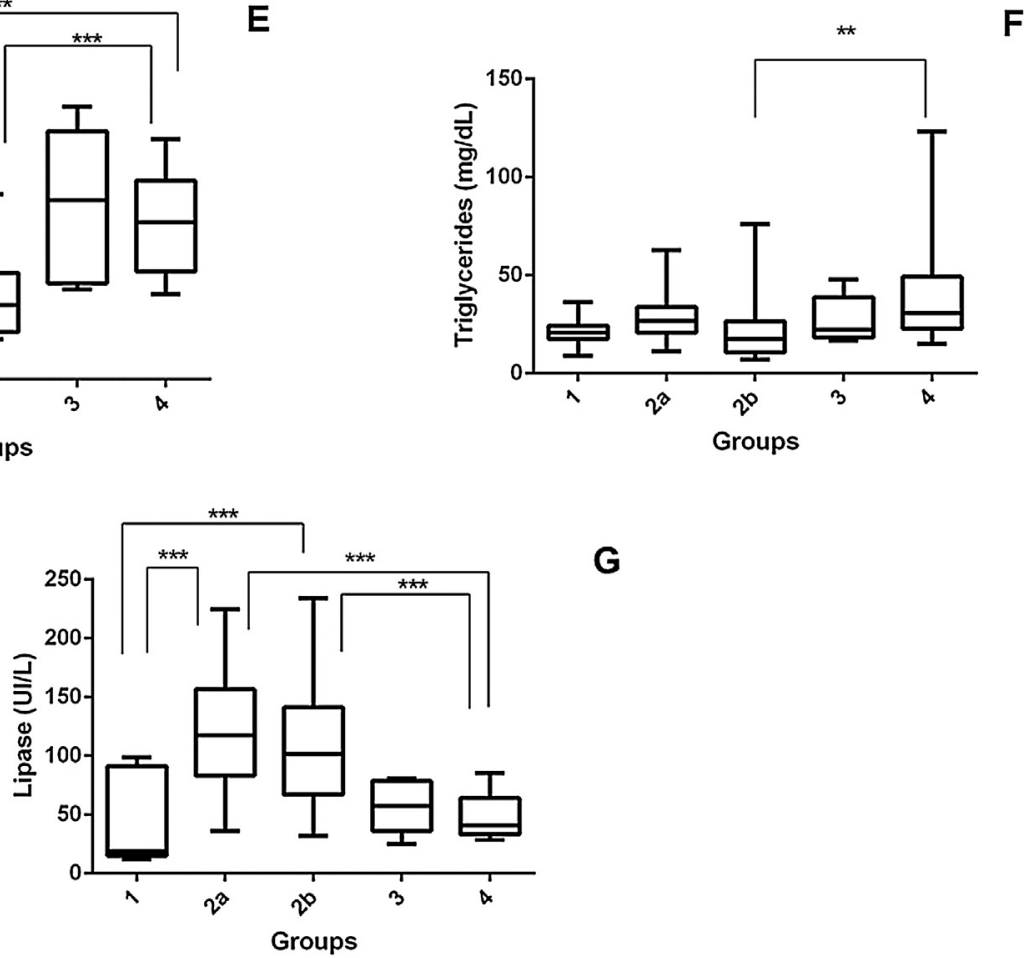

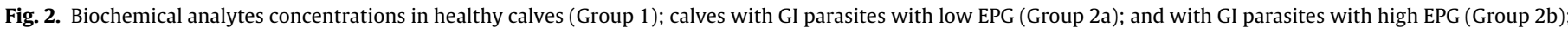

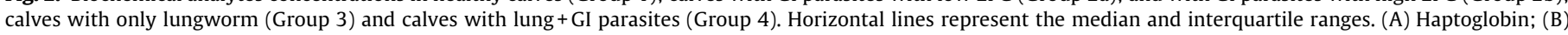
AChe; (C) Cholesterol; (D) HDL; (E) LDL; (F) Triglycerides; (G) Lipase. ${ }^{*} P<0.01,{ }^{* *} P<0.001$, ${ }^{* * *} P<0.0001$. 
Table 1

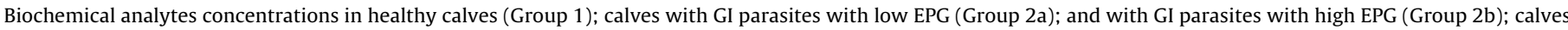
with only lungworm (Group 3) and calves with lung + GI parasites (Group 4).

\begin{tabular}{|c|c|c|c|c|c|}
\hline & Group 1 & Group 2a & Group 2b & Group 3 & Group 4 \\
\hline $\operatorname{Iron}(\mu \mathrm{g} / \mathrm{dL})$ & $\begin{array}{l}160.5 \\
{[111.8-178]}\end{array}$ & $\begin{array}{l}132.7 \\
{[97.63-161.0]}\end{array}$ & $\begin{array}{l}126.9 \\
{[95.7-169.7]}\end{array}$ & $\begin{array}{l}111.6 \\
{[105.9-161.4]}\end{array}$ & $\begin{array}{l}147.5 \\
{[113-169]}\end{array}$ \\
\hline $\mathrm{UIBC}(\mu \mathrm{g} / \mathrm{dL})$ & $\begin{array}{l}194.1 \\
{[171.1-248.3]}\end{array}$ & $\begin{array}{l}202.6 \\
{[143.8-259.9]}\end{array}$ & $\begin{array}{l}209.7 \\
{[151.3-239.7]}\end{array}$ & $\begin{array}{l}232.7 \\
{[172.3-287.4]}\end{array}$ & $\begin{array}{l}207.5 \\
{[181.2-272.3]}\end{array}$ \\
\hline Total protein (g/dL) & $\begin{array}{l}6.31 \\
{[5.97-6.99]}\end{array}$ & $\begin{array}{l}6.8 \\
{[6.44-7.15]}\end{array}$ & $\begin{array}{l}6.93 \\
{[6.03-7.26]}\end{array}$ & $\begin{array}{l}6.7 \\
{[5.88-7.22]}\end{array}$ & $\begin{array}{l}6.64 \\
{[6.35-7.06]}\end{array}$ \\
\hline Albumin $(\mathrm{g} / \mathrm{dL})$ & $\begin{array}{l}2.88 \\
{[2.54-3.0]}\end{array}$ & $\begin{array}{l}2.77 \\
{[2.64-3.02]}\end{array}$ & $\begin{array}{l}2.87 \\
{[2.64-3.1]}\end{array}$ & $\begin{array}{l}2.74 \\
{[2.61-3.01]}\end{array}$ & $\begin{array}{l}2.93 \\
{[2.75-2.98]}\end{array}$ \\
\hline Amylase (UI/L) & $\begin{array}{l}110.5 \\
{[83.63-135.2]}\end{array}$ & $\begin{array}{l}107.1 \\
{[77.05-132.6]}\end{array}$ & $\begin{array}{l}105.9 \\
{[77.4-129.8]}\end{array}$ & $\begin{array}{l}99.4 \\
{[75.6-139.7]}\end{array}$ & $\begin{array}{l}101.6 \\
{[89-121.3]}\end{array}$ \\
\hline Phosphorus (mg/dL) & $\begin{array}{l}7.78 \\
{[7.04-8.95]}\end{array}$ & $\begin{array}{l}7.64 \\
{[7.03-8.59]}\end{array}$ & $\begin{array}{l}7.27 \\
{[6.47-8.4]}\end{array}$ & $\begin{array}{l}6.9 \\
{[6.46-7.54]}\end{array}$ & $\begin{array}{l}8.3 \\
{[7.75-8.98]}\end{array}$ \\
\hline Calcium (mg/dL) & $\begin{array}{l}12.06 \\
{[11.73-12.59]}\end{array}$ & $\begin{array}{l}11.99 \\
{[11.74-12.53]}\end{array}$ & $\begin{array}{l}11.78 \\
{[11.22-12.2]}\end{array}$ & $\begin{array}{l}12.02 \\
{[11.43-12.11]}\end{array}$ & $\begin{array}{l}12.02 \\
{[11.75-12.35]}\end{array}$ \\
\hline PON-1 (UI/mL) & $\begin{array}{l}6.81 \\
{[5.25-9.26]}\end{array}$ & $\begin{array}{l}7.35 \\
{[5.46-8.75]}\end{array}$ & $\begin{array}{l}6.19 \\
{[3.9-7.05]}\end{array}$ & $\begin{array}{l}8.76 \\
{[5.93-9.38]}\end{array}$ & $\begin{array}{l}7.86 \\
{[4.55-9.69]}\end{array}$ \\
\hline BChe $(\mathrm{mmol} / \mathrm{mL})$ & $\begin{array}{l}0.55 \\
{[0.4-0.7]}\end{array}$ & $\begin{array}{l}0.6 \\
{[0.4-0.7]}\end{array}$ & $\begin{array}{l}0.5 \\
{[0.4-0.6]}\end{array}$ & $\begin{array}{l}0.7 \\
{[0.55-0.8]}\end{array}$ & $\begin{array}{l}0.6 \\
{[0.5-0.62]}\end{array}$ \\
\hline
\end{tabular}

alveoli allowing direct transfer of AChe secreted by the parasite to the animal systemic circulation, while AChe secreted by GI parasites would have to transfer across the less permeable GI barrier.

The analytes of the lipid profile decreased in our study in the calves with a high burden of GI parasites. This could indicate impairment in intestinal absorption of lipids, and diminished appetite and low digestibility of food mainly caused by the damage to the intestinal mucosae with villus flattening, and widespread loss of the superficial epithelium, produced by the GI nematodes (Hoste et al., 2010; Trapani et al., 2013). Lipase concentrations were higher in the calves with GI parasites; which could indicate a pancreatic involvement or damage as previously described in horses infected with Strongyloidea (Strongylus equinus and Stronglylus edentatus) GI parasites (Petty et al., 1992).

It is known that there could be changes in serum analytes in animals with clinical signs of disease; however, in our study the calves did not show clinical signs of parasitism. Visual inspection did not detect coughing or any respiratory signs, weight loss or pale oral mucous membrane, and feces were regular in color and consistency.

No changes in iron and UIBC were found, although hematophagous parasites such as Haemonchus spp. could produce changes in iron and UIBC (Gennari et al., 1991). In addition total protein, albumin and globulin did not change in the parasitized animals. These information suggest that the GI parasites affected mainly lipid absorption or metabolism but they did not produce significant GI blood loss which would be detected by iron or UIBC or GI protein losses or malabsorption. Phosphorus concentration did not change between groups; this could indicate that the parasites affecting respiratory system (D. viviparus) in our study conditions would not produce enough respiratory dysfunction for inducing changes in phosphorus due to respiratory alkalosis. No changes were detected in PON-1 between the groups; indicating that despite the influence that inflammation has in PON-1 (Silveira et al., 2015) in our study this enzyme has shown a lower sensitivity to detect inflammation produced by the parasites studied in calves compared to Hp. Ideally individual experimental infections with different concentrations of each of the parasites found could be made in order to properly characterize the biochemical effects produced by each species of parasites, as well the influence of the parasite burden in analytes. However, this paper provides an overview of the biochemical effects produced by nematode parasites in calves in field conditions.

\section{Conclusions}

In this study, calves were subclinically infected by low and high burdens of GI nematode parasites, by lungworm parasites alone and by concurrent infection with lungworm and GI nematodes. Both GI and pulmonary parasites increased haptoglobin concentrations, lungworms caused increases in acetylcholinesterase and only GI parasites caused decreases in the lipid profile but an increase in lipase. These findings in calves without any evident clinical signs of disease could provide an indication of GI parasites and lungworm infection, which should be considered in differential diagnosis, especially in an endemic area for these parasites.

\section{Conflict of interest}

None of the authors of this article has a financial or personal relationship with other people or organizations that could inappropriately influence or bias the content of the paper.

\section{Acknowledgements}

Marcela Cristina de Cezaro gratefully acknowledges the financial support of CAPES/Brazil. Elizabeth Moreira dos Santos Schmidt would like to thank CNPq/Brazil (PD 203241/2014-2). The authors would like to thank the Interdisciplinary Laboratory of Clinical Pathology, (INTERLAB), Campus of Excellence Mare Nostrum-University of Murcia, Spain for the laboratory analyses. We are also grateful to Raphaela Moreira de Oliveira, José Henrique das Neves, José Renato Laino Martinelli Cury, and Felipe Morales Dalanezi for the help in the sample collection and laboratory analyses.

\section{References}

Amarante, A.F.T., 2011. Why is it important to correctly identify Haemonchus species? Rev. Bras. Parasitol. Vet. 20, 263-268.

Anderson, R.C., 2000. Nematode Parasites of Vertebrates: Their Development and Transmission. CABI, 87-109 p.

Antonello, A.M., Cezar, A.S., Sangioni, L.A., Vogel, F.S.F., 2010. Eggs per gram of feces counting for anthelmintic control in dairy cattle of distinct age groups. Ciência Rural 40,1227-1230.

Borges, F.A., da Silveira, D.M., Graminha, E.B.N., Castagnolli, K.C., Soares, V.E., Nascimento, A.A., Costa, A.J., 2001. Fauna helmintológica de bovinos da região de Jaboticabal, Estado de São Paulo, Brasil. Semina: Ciênc. Agrár. 22, 49-53.

Bruhn, F.R.P., Silva Júnior, F.A., Carvalho, A.H.O., Orlando, D.R., Rocha, C.M.B.M. Guimarães, A.M., 2012. Occurrences of Eimeria spp. and gastrointestinal nematodes in dairy calves in southern Minas Gerais, Brazil. Rev. Bras. Parasitol. Vet. $21,171-175$ 
Ceciliani, F., Ceron, J.J., Eckersall, P.D., Sauerwein, H., 2012. Acute phase proteins in ruminants. J. Proteomics 75, 4207-4231.

Charlier, J., Höglund, J., von Samson-Himmelstjerna, G., Dorny, P., Vercruysse, J., 2009. Gastrointestinal nematode infections in adult dairy cattle: impact on production, diagnosis and control. Vet. Parasitol. 164, 70-79.

Eckersall, P.D., Duthie, S., Safi, S., Moffatt, D., Horadagoda, N.U., Doyle, S., Parton, R., Bennett, D., Fitzpatrick, J.L., 1999. An automated biochemical assay for haptoglobin: prevention of interference from albumin. Comp. Haematol. Int. 9, $117-124$.

Gånheim, C., Höglund, J., Waller, K.P., 2004. Acute phase proteins in response to Dictyocaulus viviparus infection in calves. Acta Vet. Scand. 45, 79-86.

Gennari, S.M., Bressan, M.V., Rogero, J.R., MacLean, J.M., Duncan, J.L., 1991. Pathophysiology of Haemonchus placei infection in calves. Vet. Parasitol. 38 , $163-172$.

Gibbs, H.C., 1992. The effects of subclinical disease on bovine gastrointestinal nematodiasis. Comped. Contin. Educ. Pract. Vet. 14, 669-677.

Gonçalves, R.C., Lisbôa, J.A.N., Sousa, M.V., Almeida, C.T., Kuchembuck, M.R.G., Chiacchio, S.B., 2000. Aspectos clínicos e epidemiológicos da broncopneumonia dos bezerros em Botucatu, SP. Rev. Bras. Ci. Vet. 7, 144-147.

Gordon, H.McL., Whitlock, H.V., 1939. A new Technique for counting nematode eggs in sheep faeces. J. Commonw. Sci. Ind. Organ. 12, 50-52.

Grisi, L., Leite, R.C., Martins, J.R.S., Barros, A.T.M., Andreotti, R., Cançado, P.H.D. León, A.A.P., Pereira, J.B., Villela, H.S., 2014. Reassessment of the potential economic impact of cattle parasites in Brazil. Rev. Bras. Parasitol. Vet. 23, $150-156$.

Höglund, J., Svensson, C., Hessle, A., 2001. A field survey on the status of internal parasites in calves on organic dairy farms in southwestern Sweden. Vet. Parasitol. 99, 113-128.

Holland, W.G., Luong, T.T., Nguyen, L.A., Do, T.T., Vercruysse, J., 2000. The epidemiology of nematode and fluke infections in cattle in the Red River Delta in Vietnam. Vet. Parasitol. 93, 141-147.

Hogg, R., Whitaker, K., Collins, R., Holmes, P., Mitchell, S., Anscombe, J., Redman, L., Gilleard, J., 2010. Haemonchosis in large ruminants in the UK. Vet. Rec. 166, 373-374.

Hoste, H., Sotiraki, S., Landau, S.Y., Jackson, F., Beveridge, I., 2010. Goat-nematode interactions: think differently. Trends Parasitol. 26, 376-381.

Jiménez, A.E., Fernández, A., Alfaro, R., Dolz, G., Vargas, B., Epe, C., Schnieder, T., 2010. A cross-sectional survey of gastrointestinal parasites with dispersal stages in feces from Costa Rican dairy calves. Vet. Parasitol. 173, 236-246.

Keyyu, J.D., Kyvsgaard, N.C., Monrad, J., Kassuku, A.A., 2005. Epidemiology of gastrointestinal nematodes in cattle on traditional, small-scale dairy and large-scale dairy farms in Iringa district, Tanzania. Vet. Parasitol. 127, 285-294.

Landim, V.J.C., Costa, A.J., Costa, G.H.N., Rocha, U.F., Barbosa, O.F., Moraes, F.R. 2001. Parasitic nematodes in weaned calves from the north-east region of São Paulo State, Brazil. ARS Vet. 17, 42-50.

Lassen, B., Bangoura, B., Lepik, T., Orro, T., 2015. Systemic acute phase proteins response in calves experimentally infected with Eimeria zuernii. Vet. Parasitol. $212,140-146$.

Lat-Lat, H., Sani, R.A., Hassan, L., Sheikh-Omar, A.R., Jeyabalan, S., Hishammfariz, M., Rohani, K., Azlan, E., Ramli, P., 2010. Lungworm of cattle in Malaysia. Trop. Biomed. 27, 236-240.

Lee, D.L., 1996. Why do some nematode parasites of the alimentary tract secrete acetylcholinesterase? Int. J. Parasitol. 26, 499-508.
McKeand, J.B., Knox, D.P., Duncan, J.L., Kennedy, M.W., 1994. The immunogenicity of the acetylcholinesterases of the cattle lungworm Dictyocaulus viviparus. Int. J. Parasitol. 24, 501-510.

Neto, M.P., Fonseca, A.H., 2002. Epidemiologia das helmintoses pulmonares e gastrintestinais de bezerros em região de baixada do Estado do Rio de Janeiro. Pesq. Vet. Bras. 22, 148-152.

Oliveira, G.P., 1988. Epidemiologia dos nematódeos gastrintestinais de bovinos leiteiros no município de São Carlos, Estado de São Paulo. Pesq. Agropec. Bras. 23, 189-195.

Petty, D.P., Lange, A.L., Verster, A., Hattingh, J., 1992. Necropsies of eight horses infected with Strongylus equinus and Strongylus edentatus. J. S. Afr. Vet. Assoc. 63, 66-69.

Ploeger, H.W., 2002. Dictyocaulus viviparus: re-emerging or never been away? Trends Parasitol. 18, 329-332.

Ministério da Agricultura, Pecuária e Abastecimento (MAPA), 2009 Programas Nacionais de Saúde Animal do Brasil. Manual de Legislação. Brasília-DF, p. 76-96, 125-142.

Radostits, O.M., Gay, C.C., Hinchcliff, K.W., Constable, P.D., 2007. Veterinary Medicine: A Textbook of the Diseases of Cattle, Horses, Sheep Pigs and Goats, 10 th ed. Saunders Elsevier, Philadelphia, pp. 2065

Roberts, F.H.S., O’Sullivan, P.J., 1950. Methods for egg counts and larval cultures for strongyles infesting the gastrointestinal tract of cattle. Aust. Agric. Rec. 1 99-102.

Rugai, E., Mattos, T., Brisola, A.P., 1954. Nova técnica para isolar larvas de nematoides das fezes-modificação do método de Baermann. Rev. Inst. Adolfo Lutz 14, 5-8.

Silva, M.C., Barros, R.R., Graça, D.L., 2005. Outbreak of dictyocaulosis in cattle in Santa Maria, RS, Brazil. Ciência Rural 35, 629-632.

Silveira, P.A., Schwegler, E., Montagner, P., Krause, A.R., Acosta, D.A., Halfen, J., Garlet, T., Barros, C.C., Corrêa, M.N., Schneider, A., 2015. Characterization of single nucleotide polymorphisms in the promoter region of the bovine paraoxonase 1 (PON1) gene affecting serum enzyme activity in dairy cows. Vet. J. 1, 101-103.

Taylor, M.A., Coop, R.L., Wall, R.L., 2007. Veterinary Parasitology, 3rd ed. Wiley-Blackwell, Iowa, pp. 874

Tecles, F., Cerón, J.J., 2001. Determination of whole blood cholinesterase in different animal species using specific substrates. Res. Vet. Sci. 70, 233-238.

Trapani, F., Paciello, O., Papparella, S., Rinaldi, L., Cringoli, G., Maiolino, P., 2013. Histopathological, histochemical and immunohistochemical findings of the small intestine in goats naturally infected by Trichostrongylus colubriformis. Vet. Parasitol. 191, 390-393.

Tvarijonaviciute, A., Tecles, F., Caldin, M., Tasca, S., Cerón, J.J., 2012. Validation of spectrophotometric assays for serum paraoxonase type-1 measurement in dogs. Am. J. Vet. Res. 73, 34-41.

Ueno, H., Gonçalves, P.C., 1998. Manual Para Diagnçsticos das Helmintoses de Ruminantes, $4^{\mathrm{a}}$ ed. Japan International Cooperation Agency, pp. 35-44.

Van Wyk, J.A., Mayhew, E., 2013. Morphological identification of parasitic nematode infective larvae of small ruminants and cattle: a practical lab guide. Onderstepoort J. Vet. Res. 80, 1-14.

Vercruysse, J., Claerebout, E., 2001. Treatment vs non-treatment of helminth infections in cattle: defining the threshold. Vet. Parasitol. 98, 195-214.

Wapenaar, W., Barkema, H.W., Eysker, M., O’Handley, R.M., 2007. An outbreak of dictyocaulosis in lactating cows on a dairy farm. J. Am. Vet. Med. Assoc. 231, 1715-1718. 